\title{
FLIPPED CLASSROOM LEARNING METHOD TO IMPROVE CARING AND LEARNING OUTCOME IN FIRST YEAR NURSING STUDENTS
}

\author{
Metode Pembelajaran Flipped Classroom Untuk Meningkatkan Sikap Caring Dan \\ Capaian Belajar Pada Mahasiswa Perawat Baru
}

\author{
Ni Putu Wulan Purnama Sari ${ }^{1}$, Anselmus Aristo Parut ${ }^{1}$, Kusnanto ${ }^{2}$ \\ ${ }^{1}$ Faculty of Nursing, Widya Mandala Catholic University Surabaya, Jl. Raya Kalisari Selatan 1, \\ Pakuwon City, Surabaya, Indonesia \\ ${ }^{2}$ Faculty of Nursing, Airlangga University, Jl. Mulyorejo, Surabaya, Indonesia \\ Jl. Raya Kalisari Selatan 1, Pakuwon City, Surabaya, Indonesia, moonygalz@yahoo.com, \\ +6285733308383 , Fax. +623199005278
}

\begin{abstract}
ABSTRAK
Pendahuluan: Caring adalah esensi dari profesi keperawatan. Stimulasi sikap caring perlu dimulai sejak dini. Metode pembelajaran yang efektif diperlukan untuk menumbuhkan sikap caring pada mahasiswa baru dan menunjang capaian belajar. Tujuan penelitian menganalisis pengaruh penerapan metode pembelajaran flipped classroom terhadap sikap caring dan capaian belajar mahasiswa perawat baru. Metode: Jenis penelitian pra-eksperimental dengan pendekatan the one group pretest post-test dan posttest only design. Populasi adalah semua mahasiswa baru pada institusi keperawatan di Surabaya. Kriteria inklusi: perempuan, 18-21 tahun, masuk jurusan keperawatan atas kemauan sendiri dan pilihan pertama saat proses seleksi, status kemahasiswaannya aktif pada semester genap T.A. 2015/2016. Besar sampel 67 orang dipilih dengan total sampling. Variabel: 1) independen: penerapan metode pembelajaran flipped classroom; 2) dependen: sikap caring, capaian belajar. Instrumen: SAP, DVD bahan ajar, deskripsi tugas mahasiswa, daftar presensi, rubrik penilaian tugas, kuesioner sikap caring, tugas individu dan kelompok. Analisis data: paired $t$ test dan one sample $t$ test. Uji etik dilakukan untuk mendapatkan ethical clearance. Hasil: Mayoritas responden berusia 20 tahun $(44,8 \%)$, lulus dari SMA di wilayah Surabaya $(38,8 \%)$, tinggal dengan orangtuanya $(68,7 \%)$ di rumah sendiri $(64,2 \%)$. Semua data penelitian berdistribusi normal. Metode pembelajaran flipped classroom dapat meningkatkan sikap caring sebesar 4,13\%. Flipped classroom terbukti efektif untuk meningkatkan sikap caring $(\mathrm{p}=0,021)$ dan capaian belajar $(\mathrm{p}=0,000)$. Diskusi: Flipped classroom efektif untuk meningkatkan sikap caring dan capaian belajar mahasiswa perawat baru. Direkomendasikan untuk melakukan penelitian lanjutan menggunakan paradigma mix-method dan sampel yang lebih besar.
\end{abstract}

Kata Kunci: flipped classroom, sikap caring, capaian belajar, mahasiswa perawat, pendidikan keperawatan

\begin{abstract}
Introduction: Caring is the essence of the nursing profession. The stimulation of caring attitude should start early. Effective teaching methods needed to foster a caring attitude and improve learning achievements. This study aimed to explain the effect of applying the flipped classroom learning method to improve the nurse's caring attitude and the learning achievement of new student nurses at nursing institutions in Surabaya. Methods: This was a pre-experimental study using a one group pretest-posttest and posttest only design. The population was all of the new student nurses in nursing institutions in Surabaya. The inclusion criteria were that they were female, 18-21 years old, majoring in nursing of their own volition and that it had been their first choice during the students selection process, and that their nursing status was active in the semester of the 2015/2016 academic year. The sample size was 67 nurses, selected through total sampling. Variables: 1) independent: the application of a flipped classroom learning method; 2) dependent: caring attitude and learning achievement. Instruments: teaching plan, assignment descriptions, presence list, assignment assessment rubrics, study materials and the questionnaires on the caring attitude. Data analysis: paired and one sample t-test. Ethical clearance was available. Results: Most of the respondents were 20 years old (44.8\%), had graduated from high school in Surabaya $(38.8 \%)$ and were living with their parents (68.7\%) in their homes (64.2\%). All of the data was normally distributed. The flipped classroom learning method improved the caring attitude by $4.13 \%$. The flipped classroom learning method was proven to be useful at enhancing caring attitude $(p=0.021)$ and the learning achievements $(p=0.000)$. Discussion: The flipped classroom method was effective at improving the nurse's caring attitude and the learning achievement of new nursing students. It is recommended to use a mixed methodology approach and a larger sample for further study.
\end{abstract}

Keywords: flipped classroom, caring attitude, learning achievement, student nurse, nursing education

\section{INTRODUCTION}

The flipped classroom is an instructional model which is flipping the traditional learning method used in class, with it now being the homework for college students. This is while classes are conducted face to face using collaborative learning and inquiry-based learning methods. This model is often called the inverted classroom because what was previously done in the classroom is now done in-house or somewhere else, and what used to be done at home is now 
completed in the classroom (Bergmann and Sams, 2012). The flipped/inverted classroom is a modification of the instructional models centered on the student and has been developed over a long time (Felder, 2012) Various studies have been conducted to prove the effectiveness of the flipped classroom learning method at improving the students' learning motivation and satisfaction (Butzler, 2014). The flipped classroom can be applied to students who have a high level of independence in their learning and who want some flexibility in the time and place of their learning. Related to the nursing education institutions in Indonesia in their efforts to improve the attitude of caring and learning achievement in the student nurses, the flipped classroom learning method has not been widely implemented.

A caring attitude is the very essence of nursing. The stimulation of a caring attitude needs to be done early on for new students so then they can be a nurse who cares for their clients and who has a high level of empathy. The learning method of flipped classroom support is an active learning process that provides more significant opportunities for students to interact with various types of knowledge content through reading, writing, speaking and reflecting on things that have been studied independently (University of Minnesota, Center of Learning and Education, 2008; in Hamdan, et al., 2013). Research shows that active learning can improve the students' academic performance (Michael, 2006; Freeman et al., 2007; Chaplin, 2009; in Hamdan, et al., 2013), improve their critical thinking skills and student engagement with the scientific field and create a positive attitude to learning (O'Dowd \& Aguilar-Roca, 2009; in Hamdan, et al., 2013). The results of the application of the flipped classroom learning method for improving the caring attitude and learning achievement of students, especially new student nurses, has not been studied frequently.

According to Johnson (2013), the flipped classroom is a strategy given by educators to minimize the amount of direct instruction in the student's practices while maximizing their interactions with one another. The flipped classroom lessons allow th students to access knowledge content at anytime and anywhere. The educators can use multimedia technology, either made or downloaded from trusted sites (Hamdan et al., 2013). A flipped classroom allows the students to learn outside of the classroom. During the learning process in the classroom, the student is ready to apply what they have learned. The role of the teacher or lecturer in the classroom is as a facilitator who spends more time interacting with the students. Based on the revision of Bloom's taxonomy (2001), the flipped classroom means that the lowest level of taxonomy (understand and remember) is done outside of the classroom, while the highest level (apply, analyze, evaluate and produce) is done inside the classroom and facilitated by the lecturers (Marshall, 2013).

Several factors support the need to implement a flipped classroom learning method, including excess study materials and the fact that the students expect variations in the learning process (Bristol, 2014). By motivating students to come to the class through the preparation of the material that is to be learned, the freed instructional time is used to improve the application and analysis, resulting in more practical learning abilities. According to Valiga (2012), the nurse educators no longer give the lecture in the traditional way, but they use the flipped classroom learning method, so then time with the students will be focused on learning to think critically.

According to Hamdan et al. (2013), there are four main pillars involved in the implementation of the flipped classroom learning method, namely: 1) a flexible environment; 2) changed in the culture of learning; 3) the existence of clear learning objectives and 4) professional lecturers/facilitators. There are many benefits to be gained through the application of the flipped classroom learning method, namely: 1) the classroom lessons are more widely used to review and discuss a topic that is difficult to understand by the students (Center for Digital Education, 2012); 2) the students learn how to collaborate, communicate and practice their leadership skills (Chen, 2014); 3) the lecturer did not waste time to answering standard questions and any questions that are repeatedly asked (Center for Digital Education, 2012); 4) the students learn more from realistic learning experiences (Bristol, 2014); and 5) it improves the lecturers' competence (Bristol, 2014).

Research on the flipped classroom learning method has been not done much, 
either qualitative or quantitative. However, some supporting studies have the same principles as the flipped classroom learning method. Research conducted by Chaplin (2009) showed that active learning increases student achievements. A similar study conducted at the University of Minnesota also showed that active learning gives the students more opportunity to interact through reading, writing, listening and speaking, and to reflect what they have learned (Center of Learning and Education, 2008). Active learning also improves critical thinking skills and the attitude of the students (O'Dowd, 2009). Musallam's study (2010) showed that students who had studied the material beyond the previous class more easily understood the material provided in the classroom.

Research by Papadopoulos \& Roman (2010) conducted on mechanical engineering students showed a video tutorial given by the lecturer that was then studied by students alone. After that, it was discussed in the class to make sure that the students understand the materials more quickly, and they showed outstanding progress. Another survey conducted on 450 lecturers showed that lecturers who use the flipped classroom learning method reported an increased ability/mark (66\%) and attitude (80\%), in addition to an improved level of teaching satisfaction in the lecturers $(90 \%)$ (Flipped Learning Network, 2012). However, not all of the studies on the flipped classroom learning method gave a positive result. The success of the flipped classroom learning method is also influenced by the students' interest in the particular materials or given subjects (Strayer, 2012).

The objective of this study was to explain the effect of the application of the flipped classroom learning method on the caring attitude and learning achievement of new student nurses in nursing institutions in Surabaya.

\section{METHODS}

This was a pre-experimental study using the one group pre-test-post-test and posttest-only design approach. The population was all of the new student nurses in the nursing institutions in Surabaya. The affordable population was all of the new student nurses at the Faculty of Nursing, University A (accredited A); at the Faculty of Nursing,
University B (accredited B) and who were attending the College of Health Sciences C (accredited C) in the 2015/2016 academic year. The sample consisted of the freshmen at the three institutions which met the sample criteria. The inclusion criteria consisted of women who were 18-21 years old majoring in nursing on their own volition and with it being their first choice during the student's selection process. The student's status was that they were active in the second semester of the 2015/2016 academic year. The exclusion criteria consisted of if they had resigned in the middle of the study, if they did not attend all class meetings, if they did not do th collected assignments (individual or group) or if they were not timely at completing the collected assignments. Out of the 210 new student nurse population at all three institutions used as study location, 67 students met the criteria. The sample size was not calculated based on any formula because all of the members of the population were being studied (total sampling).

This study was conducted on the new student nurses at three nursing institutions in Surabaya (accredited A, B, and C) in the 2015/2016 academic year with the facilitator being the research team itself. Face to face meetings in the classroom were planned to take place 4 times for 100 minutes over 2 weeks, carried out in the classroom of each institution by taking extra hours in addition to the formal ongoing learning process. The data collection of the pre-test and post-test was conducted in June - August, 2016.

The study variables consisted of 1) the independent variable: the application of the flipped classroom learning method, 2) the dependent variables: attitude of caring and learning achievement, 3) the control variables of the teaching materials, the frequency of face to face meetings in the classroom, the given assignments, lesson facilitators; and 4) the confounding variables of learning motivation, independence, study load, stress, and the environment. The instruments used for applying the flipped classroom learning method were the teaching plan, assignment description (individual and group), presence list and the DVD of the study materials. The teaching plan provided details of the teachinglearning activities between the facilitators and respondents in four scheduled meetings, each lasting 100 minutes. The assignment 
description contained the problems/topics, how to do systematic report writing and the deadline, etc. The DVD materials were divided into 11 folders consisting of of the theoretical study materials, such as critical thinking, th flipped classroom, health issues, nursing concepts, family health, public health, environmental health, nursing innovations, chronic diseases, student-centered learning (SCL) and the theory of caring.

The caring attitude was assessed by a questionnaire designed by Rika (2012), which was slightly modified by the research team. The questionnaire consisted of 36 statements based on the 10 carative factors involved in the theory of caring as proposed by Jean Watson. Each statement was assessed using a Likert scale of 1 to 4: always $=4$, often $=3$, sometimes $=2$ and never $=1$. The results of the instrument testing on 33 respondents proved that the questionnaire was valid $(\mathrm{r}=$ 0.346 to 0.796 ) and that it had a high level of reliability $(\alpha=0.939)$. The data scale used was an interval. The score ranged from 36 to 144 . Each item for all of the statements was assessed by scoring the guidelines and then summarizing them to obtain the total score. They were then put into a statistical test (test of the data's normality and paired ttest).examination). The study hypothesis was accepted if the significance of the data was less than $\alpha(0.05)$.

The learning achievement was assessed through the individuals, and the group assignments were collected in a timely manner according to the assignment assessment rubrics. The individual assignment was done independently while the group assignments were done collaboratively with each group consisting of 5-6 students. The assignment assessment rubrics for the individuals and in the groups were made differently to facilitate a more detailed assessment; the group assignments involved the aspects of teamwork and cooperation, leadership, tolerance, and communication that were not found in the individual tasks. The data scale used was a ratio. The score range was 0 to 100 . The score of the individual assignment was summed with the group assignment and then averaged, before it was input into a statistical test (test of the data's normality and one sample t-test). The study hypothesis was accepted if the significance of the data was less than $\alpha(0.05)$.

The ethical review was conducted by the Faculty of Nursing, Airlangga University, Surabaya, Indonesia. This was done in order to obtain ethical clearance. The other ethical aspects that were applied were informed consent, anonymity and confidentiality.

\section{RESULTS}

The sample consisted of 67 students. The demographic characteristics of the study respondents have been presented in Table 1 . Most of the respondents were 20 years old or young adults (44.8\%), who had graduated

Table 1. Demographic characteristics $(n=67)$

\begin{tabular}{lcc}
\hline Characteristics & Frequency & \% \\
\hline Age & 5 & \\
18 years old & 28 & 7.5 \\
19 years old & 30 & 41.8 \\
20 years old & 4 & 6.8 \\
21 years old & 26 & \\
Graduated from & 21 & 38.8 \\
High school in Surabaya & 5 & 31.3 \\
High school in East Java & 15 & 7.5 \\
High school in Java & & 22.4 \\
High school outside Java & 46 & 68.7 \\
Living with & 9 & 13.4 \\
Parents & 4 & 6.0 \\
Siblings & 15 & 22.4 \\
Extended family & & \\
Friends & 43 & 64.2 \\
Housing status & 7 & 10.4 \\
Owner & 17 & 25.4 \\
Renter (a house) & & \\
Renter (a room) & & \\
\hline
\end{tabular}


Table 2. Primary Data $(n=67)$

\begin{tabular}{lcc}
\hline \multicolumn{1}{c}{ Characteristics } & Frequency & $(\%)$ \\
\hline The reason why they chose the nursing major & 7 & 10.4 \\
Making their family proud & 13 & 19.4 \\
Willing to care for a family member & 36 & 53.7 \\
Dream/personal preference & 23 & 34.3 \\
Helping each other & 1 & 1.5 \\
Teacher's advice & 9 & 13.4 \\
Job market & 4 & 6 \\
More quota available & 1 & 1.5 \\
Friends' recommendation & & \\
The reason why they chose their current institution & 13 & 19.4 \\
Near to their home & 31 & 46.3 \\
Good image in the community & 5 & 7.5 \\
Good accreditation & 2 & 3 \\
Great alumni & 4 & 6 \\
Teacher's advice & 3 & 4.5 \\
Unaccepted in a public institution & 7 & 10.4 \\
Friends' recommendation & 11 & 16.4 \\
Low tuition fee & 7 & 10.4 \\
Perceived to be able to fulfill their personal goals & 1 & 1.5 \\
Randomly chosen & 1 & 1.5 \\
Being forced to choose & & \\
\hline
\end{tabular}

Table 3. Caring attitude pre-test and post-test

\begin{tabular}{cccccc}
\hline Score & \multicolumn{2}{c}{ Pre-test } & \multicolumn{2}{c}{ Post-test } \\
\cline { 2 - 6 } & $\mathbf{n}$ & $\mathbf{\%}$ & $\mathbf{n}$ & $\mathbf{\%}$ \\
\hline $36-72$ & 1 & 19.4 & 11 & 0 \\
$73-108$ & 13 & 79.1 & 56 & 16.4 \\
$109-144$ & 53 & &
\end{tabular}

Table 4. Cross table of the pre-test and post-test the data of caring attitude

\begin{tabular}{|c|c|c|c|c|c|c|c|c|}
\hline \multirow{3}{*}{ Pre-test } & \multicolumn{6}{|c|}{ Post-test } & \multirow{2}{*}{\multicolumn{2}{|c|}{ Total }} \\
\hline & \multicolumn{2}{|c|}{$36-72$} & \multicolumn{2}{|c|}{$73-108$} & \multicolumn{2}{|c|}{$109-144$} & & \\
\hline & f & $\%$ & f & $\%$ & f & $\%$ & $\mathbf{F}$ & $\%$ \\
\hline $36-72$ & 0 & 0 & 0 & 0 & 1 & 1.5 & 1 & 1.5 \\
\hline $73-108$ & 0 & 0 & 3 & 4.5 & 10 & 14.9 & 13 & 19.4 \\
\hline $109-144$ & 0 & 0 & 8 & 11.9 & 45 & 67.2 & 53 & 79.1 \\
\hline \multicolumn{3}{|c|}{$\begin{array}{l}\text { Paired Mean } \pm S D \\
4.94 \pm 17.12\end{array}$} & Er & $(S E)$ & & \multicolumn{3}{|c|}{$\begin{array}{l}\text { Paired t-test Sig. (2-tailed) } \\
p=0.021\end{array}$} \\
\hline
\end{tabular}

Table 5. Posttest-only data of learning achievement

\begin{tabular}{|c|c|c|c|c|c|c|}
\hline \multirow[t]{2}{*}{ Score } & \multicolumn{2}{|c|}{ Individual Task } & \multicolumn{2}{|c|}{ Group Task } & \multicolumn{2}{|c|}{ Mean } \\
\hline & $\mathbf{n}$ & $\%$ & $\mathbf{n}$ & $\%$ & $\mathbf{n}$ & $\%$ \\
\hline $0-33$ & 0 & 0 & 0 & 0 & 0 & 0 \\
\hline $34-67$ & 0 & 0 & 0 & 0 & 0 & 0 \\
\hline $68-100$ & 67 & 100 & 67 & 100 & 67 & 100 \\
\hline Mean $\pm S D$ & \multicolumn{2}{|c|}{ Std. Error Mean (SEM) } & \multicolumn{2}{|c|}{ One sample t test } & & \\
\hline $86.19 \pm 5.1$ & \multicolumn{2}{|c|}{0.62} & \multicolumn{2}{|c|}{$\begin{array}{l}\text { Sig. (2-tailed) } \\
p=0.000\end{array}$} & & \\
\hline
\end{tabular}

from high school in Surabaya (38.8\%) and who were living with their parents $(68.7 \%)$ in their own homes $(64.2 \%)$. In this study, the majority of the nursing students were first exposed to a clinical environment (clinical nursing practice) at the age of 19-20 years old.

The primary data reflects the motivation of the respondents in choosing a nursing majors and a corresponding institution. The primary data was essential to identify because it could potentially influence the students' learning motivation, where the researchers assume that learning motivation correlates to learning achievements. The primary data of the respondents has been presented in Table 2. 
Most of the respondents chose to study a nursing majors as they had a dream of being a nurse or they personally preferred to study the health sciences, especially nursing science $(53.7 \%)$. The majority chose their current institution because of its good image in the community $(46.3 \%)$.

The Kolmogorov-Smirnov test results showed that the data pre-test and post-test for caring attitude were normally distributed $(\mathrm{p}=$ 0.642 ). The caring attitude data before and after the application of the flipped classroom learning method has been presented in Tables 3 and 4 below.

The results showed that the score of the pre-test was mostly 109-144 for as many as 53 respondents $(79.1 \%)$. The score of the post-test were also mostly 109 - 144 for as many as 56 respondents $(83.6 \%)$.

There was an increase of $4.13 \%$ for caring attitude after the application of the flipped classroom learning method.

One respondent $(1.5 \%)$ showed a significant increase in caring attitude, from 36 - 72 to 109 - 144. Also, 10 respondents (14.9\%) experienced an improvement in caring attitude, from 73 - 108 to 109 - 144. It was also found that 8 respondents $(11.9 \%)$ were impaired, and their score of caring attitude decreased from 109 - 144 to 73 - 108.

The paired mean value was 4.94 with an SD of 17.12. The mean value of caring attitude pre-test was 119.5, and post-test it was 124.4. The SD value of less than the mean indicates a low standard deviation of the caring attitude data. The SEM value of 2.09 indicates the value of the mean representative used to describe the entire caring attitude data. The paired t-test result showed that the p-value $=0.021$, which means that there was an effect from the application of the flipped classroom learning method toward the caring attitude of new student nurses. The implementation of the flipped classroom learning method was proven to be effective at increasing the caring attitude in new student nurses.

The Kolmogorov-Smirnov test result showed that the post-test-only data of the learning achievements was normally distributed $(p=0.204)$. The results of the learning achievement after the application of the flipped classroom learning method have been presented in Table 5 below.
The values of learning achievement post-test were entirely in the range of 68 - 100, for as many as 67 people (100\%). No respondents scored less than 68 because of the intensive supervision from the flipped-class instructor.

The mean value obtained was 86.19 with an SD 5.1. This is less than the mean, which indicates a low standard deviation of the data observations for learning achievement. The SEM value of 0.62 indicates the value of the mean that is representative at describing the entire data for the learning achievements. The one sample t-test result showed that the pvalue $=0.000$, which means there was an effect from the applied flipped classroom learning method to learning achievement in new student nurses. The implementation of the flipped classroom learning method has a positive effect on the new student nurses' learning achievements.

\section{DISCUSSION}

Bishop and Verleger (2013) describe flipped classroom learning as a learning technique that requires two things; the interactive group learning activities in the classroom and direct computer-based individualized instruction outside the classroom. The Flipped Classroom means that the lowest level of the Bloom Taxonomy (understand and remember) is done outside of school hours, while the highest levels (apply, analyze, evaluate and produce something) are done in the classroom and facilitated by the lecturers.

In this study, the students were given two tasks in the form of individual and group assignments. The students were free to choose the topics (health problem) that exist around them as individual tasks and they chose other health issues with broader coverage as the group task. The students were then asked to write a paper containing proposed solutions to the health problems that they had chosen, in order to assess their caring attitude to and in their surroundings.

Based on this study, there was a significant effect from the application of the flipped classroom learning method on the caring attitude in the new student nurses ( $p=$ 0.021). The flipped classroom method benefits both students and the faculties. Regarding the students, there are increases in their learning flexibility because they are required to be 
more focused and able to not only learn in the classroom, but outside of the classroom as well (Moraros et al., 2015). The students were required to improve their critical thinking skills and more importantly, their "peer teaching" and active discussion skills in the classroom. From the perspective of the faculties, the flipped classroom method makes it easier to engage and trick the students into being more active in the learning process. The flipped classroom not only allows ofr th faculties to give the students a broader variety of teaching materials, sources and a deeper understanding of the studied materials, but it also prompts active discussions in the classroom to help the students to be more enthusiastic in understanding studied problems (Moraros et al., 2015).

A survey of 450 lecturers showed that the lecturers who implemented the flipped classroom learning method reported an increased ability and attitude in their students, as well as improved job satisfaction in the lecturers themselves; $66 \%$ of lecturers reported an increase in the students' score. Eight out of 10 lecturers reported an increase in the student's attitude. Nearly $90 \%$ of lecturers reported increased satisfaction with their work, with 46 reporting a very significant increase (Flipped Learning Network, 2012).

The research of Gillispie (2016) was conducted on medical students using a casecontrol design, in which the class using the traditional method was the control group and the class using the flipped classroom learning method was the intervention group. The results showed that the intervention group had a significantly increased score compared to the control group.

The research of Papadopoulos \& Roman (2010) was conducted on mechanical engineering students. The students are given a tutorial video and had to learn it by themselves, before holding discussions in the class. Based on the observations of the researchers, the students captured the knowledge more quickly and had very good progress. But not all studies on the flipped classroom method have had a positive result. The success of the flipped classroom method application is also influenced by the student's interest in the material provided (Strayer, 2012).

Overall, the flipped classroom method gives students the opportunity to be more critical in their thinking, more independent in their learning process, and more active when interacting and discussing both with their peers and the faculty. In this study, the researchers also found 8 respondents $(11.9 \%)$ who were impaired in the caring attitude posttest. According to the research of Lape (2014), there are some challenges encountered when implementing the flipped classroom method, namely that students who have a slower ability when it comes to understanding the material left behind by students who have a quick comprehension. Acedo (2013) described some of the some negative opinions of flipped classroom learning, such as the flipped classroom cannot be applied to students of a poor economic status, as the method requires them to have a laptop. The flipped classroom depends on the preparation and confidence conducted. The lecturers must trust that the students have studied the material given independently, when there is no guarantee that the students will be cooperative and do independent learning outside of the classroom. By applying the flipped classroom method, the students spend more time in front of the computer.

Based on this study, there is a significant effect from the application of the flipped classroom learning method on learning achievement in new student nurses $(\mathrm{p}=0.000)$. Learning achievement is operationally defined as the students' comprehensive understanding of a discussed topic on caring attitude expressed in a written paper through individual and group assignments, scored using a special rubric. The tasked respondents feel active in the self-learning experience and are able to individualize their learning experience. The respondents were asked to scrutinize health issues within their family and the community, and they were then required to propose a solution to the problems found. The most important aspect emphasized in the task given is that their caring attitude to be able to recognize health problems well and that their level of critical thinking to be able to analyze actual or potential health issues.

In this study, the students also took part in individual and group tasks collaboratively with the facilitator in the classroom where the originality of the idea and topic came from the students themselves according to their learning needs. The facilitator must help the completion process of 
all tasks through consultations/guidance and interactive discussions. In principle, the flipped classroom method emphasizes the aspects of collaborative learning in the scheme of student-centered learning in a constructivist learning environment.

The core concept of constructivism applied to the learning process is the studentoriented learning environment where the student's knowledge and understanding are socially constructed (Felder, 2012; Perkins, 1999; Sternberg, 2008; in Butzler, 2014). The application of th flipped classroom learning method involves combining multiple teaching methods, namely problem-based learning (PBL), inquiry learning, just-in-time teaching (JiTT), process-oriented guided inquiry learning (POGIL), and Peer Instruction (PI) (Crouch \& Mazur, 2001; Herreid and Schiller, 2013; Prince \& Felder, 2006; Prince \& Felder, 2007; in Butzler, 2014). The students build their own thoughts and change their existing mindset through the learning material. They collaborate socially with other students and instructors / facilitators (Felder, 2012; Perkins, 1999; Prince \& Felder, 2006; Prince \& Felder, 2007; Sjöberg 2007; Sternberg, 2008; in Butzler, 2014).

The flipped classroom learning method has a complex structure that requires an instructional design that has been compiled carefully, as well as care being taken in its implementation. The focus of this method is a set of inversions and connections between the instructional design and the implementation of the learning methods. The main goal of this method is the emergence of an active learning environment in the classroom. This method builds good relationships between the faculty and the student to create a more differentiated learning instruction (according to the progress of student learning) and to promote the increased involvement of students in the classroom (Brown, 2012).

The research of Hantla (2014) concerning the application of the flipped classroom focused on aspects of critical thinking that showed that the students' argument written in their papers used rational scientific reasons and evidence when compared with traditional methods ( $\mathrm{p}<$ 0.001 ). Viewed from the aspect of innovation and due to the internalization of the learning experience, the flipped classroom provides a more conducive learning environment than traditional classrooms. The lecturer, who became an instructor in the flipped classroom, also stated that he had more time in the classroom to be able to focus on the written arguments. Additionally, the method also makes the students more innovative in the classroom environment, with full autonomy.

There are two major problems in the application of the flipped classroom learning method. The first problem is that there is very little scientific evidence indicating that the achievement of student learning is better through the application of the flipped classroom method (Lage et al., 2000; Mazur, 2009; Strayer, 2012; Zappe et al., 2009; in Butzler, 2014). The second problem is that not all students are ready academically or have the necessary motivation to achieve success in learning in a constructivist learning environment as happened in the flipped classroom (Kirschner et al., 2006; Lavasani \& Ejei, 2011; Liu et al., 2012; in Butzler, 2014). The effectiveness of the flipped classroom learning method application in relation to learning achievements in new student nurses is potentially influenced by various unidentified factors in this study that need further investigation.

The first factors that potentially affect the effectiveness of the flipped classroom learning method application are the individual's characteristics. The success and satisfaction of learning in any learning environment is influenced by the individual's characteristics (Baeten et al., 2010; Baeten et al., 2013; in Butzler, 2014). The first characteristic is learning motivation. In this study, the inclusion criteria included that the students on the nursing study program should be based on their own volition and that the institution should be their first choice during the selection process. According to these criteria, the researchers hope that all of the respondents already had a good level of motivation to seriously study the science of nursing, particularly the matter of caring as the essence of nursing. The results showed that the majority chose the nursing major because of personal interest or because they were aspiring to become nurses (53.7\%). Learning motivation level can influence learning achievement and satisfaction in the implementation of a constructivist learning environment as happened in the model of the flipped classroom (Hill, 2013; Jaschik, 2013; 
Lavender, 2005; Liu et al, 2012; Lopez-Perez, et al, 2011; Ning \& Downing, 2012; Rastegar, et al, 2010; Soenens \& Vansteenkiste, 2005; Vansteenkiste, et al, 2009; in Butzler, 2014). Typically, the intrinsic motivation of students increased in a constructivist learning environment (Baeten et al., 2010; cent and Tarhan, 2010; Vansteenkiste et al., 2009; Vos et al., 2010; in Butzler, 2014).

The second characteristic is the student's interest in the topic/study material. The success of the flipped classroom learning method application is affected by the interest of the students in the material provided (Strayer, 2012). The flipped classroom learning method is able to make the students learn actively and independently, and the students can individualize their learning experiences so then they can learn things that are considered important to them according to their learning needs (McDonald \& Smith, 2013). The third characteristic is prior knowledge. The level of the students' knowledge possessed before the application of the flipped classroom method affected the student's learning achievements and their satisfaction with the implementation of the method (Kettle, 2013; Niemic \& Ryan, 2009; Ning \& Downing, 2012; Vansteenkiste et al., 2009; in Butzler, 2014).

The second factor that could potentially affect the effectiveness of the flipped classroom learning method application is the study materials. The current university student population is often labeled the Net Generation. The students nowadays use digital technology to construct their own knowledge and thinking based on the information obtained from the electronic media. The study materials used in the application of the flipped classroom learning method is in the digital/electronic format. Therefore, the Net Generation should be satisfied when learning according to the flipped classroom method (Prensky, 2001; Beyers, 2009; Oblinger \& Oblinger, 2005; Roberts, 2010; Tapscott, 2009; in Butzler, 2014).

The third factor that can potentially influence the effectiveness of the flipped classroom learning method application is the instructor/facilitator. This method requires a professional faculty member as the instructor. There are four phases that need to be passed through by the lecturers before they can change their method of ordinary teaching into the instructional models of flipped classroom. These phases are: 1) motivation for change, 2) preparation of the cognitive elements and curriculum, 3) changes in the pedagogy and teaching practices, transitioning into becoming more of a constructivist learning environment, and 4) it reflects the benefits and challenges of adopting a new learning model (Yemma, 2015). The lecturers need to be prepared before facilitating the flipped classroom method of learning through courses / special training (Kowalski \& Horner, 2015). McDonald and Smith (2013) argue that the effectiveness of this method depends on the flipped classroom professional educators who are trained in observing and monitoring the progress of students.

The fourth factor that could potentially affect the effectiveness of the flipped classroom learning method application is the time available for study. The flipped classroom is very effective when there is not enough time or a very limited amount of time available for face to face meetings in the classroom. Just in Time Teaching (JiTT) refers to the application of this method in which means face-to-face classes are only held according to the student's needs (Butzler, 2014). This method is very effective for students who are very busy, because the study materials can be learned outside of class at very flexible times (McDonald \& Smith, 2013).

The respondents had a positive response to the implementation of the flipped classroom learning method in this study. The respondents said that they understood how to make a good paper, how to do the task better and how to improve their workmanship. The lecturers also did not need to explain too much about the subject matter but, through the direct application of the tasks, the method does not bind the students and lecturers to an exact time for face to face meetings as in classroom/class schedules. The method of learning is more effective so then students could explore the subjects given. It is recommended to conduct further study using the mixed-method paradigm and a larger sample size together with experienced/trained flipped classroom instructors. This is so then the effectiveness of nursing education can be better identified and evaluated. 


\section{CONCLUSION}

The application of a flipped classroom learning method is effective at improving the caring attitude and learning achievement in new student nurses. The lecturers are advised to follow a course/training about the flipped classroom model before applying it to their students, while also conducting a survey of the student's learning needs before making the study materials. The students are suggested to increase their learning independence and motivation, to encourage them to be more cooperative in a flipped class learning environment. Other researchers can then conduct further research using a mixedmethod paradigm and a larger sample size together with experienced/trained flipped classroom instructors. This is so then the effectiveness of nursing education can be identified and evaluated.

\section{REFERENCES}

Acedo, M. (2013). 10 Pros and Cons Of A Flipped Classroom. http://www.teachthought.com/learning blended-flipped-learning/10-proscons-flipped-classroom/ Diakses pada 10 September 2016 jam 21.10

Bergmann, J., \& Sams, A. (2012). Flip your classroom: Reach every student in every class every day. Eugene, OR: International Society for Technology in Education.

Bishop, J., Verleger, M., et al. (2013). The Flipped Classroom: A Survey of The Research. 120th ASEE Annual Conference and Exposition. American Society for Engineering Education

Bristol, T. (2014). "Flipping the Classroom." Teaching and Learning in Nursing 9.1 (2014): 43-46. Print.

Brown, A. F. (2012). A Phenomenological Study of Undergraduate Instructors Using the Inverted or Flipped Classroom Model. Dissertation. Diunduh dari www.proquest.com

Butzler, K.B. (2014). The Effects of Motivation on Achievement and Satisfaction in a Flipped Classroom Learning Environment. Diunduh dari: www.proquest.com

Center For Digital Education. 2012. The Flipped Classroom: Increasing
Instructional Effectiveness in Higher Education with Blended Learning Technology. http://echo360.com/sites/default/files/ Flipped\%20Classroom\%20Brief.pdf

Felder, R.M. (2012). Engineering education-A tale of two paradigms. In SFGE, 2nd. International Conference on Geotechnical Engineering Education, Galway.

Gillisipie, V. (2016). Using the Flipped Classroom to Bridge the Gap to Generation Y. Ochsner Journal. 16:32-36

Hamdan, N., McKnight, P., McKnight, K., \& Arfstrom, K.M. (2013). "A Review of Flipped Learning." Flipped Learning Network. Flipped Learning Network, 2013. PDF file. 27 Aug. 2014. http://www.flippedlearning.org/cms/li b07/

VA01923112/Centricity/Domain/41/L itReview FlippedLearning.pdf

Hantla, B. F. (2014). The Effects of Flipping the Classroom on Specific Aspects of Critical Thinking in A Christian College: A Quasi-Experimental, Mixed-Methods Study. Dissertation. Diunduh dari www.proquest.com

Johnson, L., \& Renner, J. (2012). Effect of the flipped classroom model on secondary computer applications course: student and teacher perceptions, questions and student achievement (Doctoral Dissertation, University of Louisville).

Marshall, H. W. (2013, March 21). Three reasons to flip your classroom. Retrieved from http://www.slideshare.net/lainemarsh/ 3-reasons-to-flip-tesol-2013-32113

McDonald, K., Smith, C. M. (2013). The Flipped Classroom for Professional Development: Part I. Benefits and Strategies. J. Contin. Educ. Nurs. 44(10): 437-438

Moraros, J. (2015). Flipping for Success: Evaluating the Effectiveness of $\mathrm{A}$ Novel Teaching Approach in A Graduate Level Setting. BMC Medical Education. 15:27

Musallam, R. (2010). The effects of screencasting as a multimedia pretraining tool to manage the intrinsic load of chemical equilibrium instruction for advanced high school 
$\begin{array}{lll}\text { chemistry } & \text { students } & \text { (Doctoral } \\ \text { Dissertation, University of San } \\ \text { Francisco). }\end{array}$

O'Dowd, D. K., \& Aguilar-Roca, N. (2009). Garage demos: using physical models to illustrate dynamic aspects of microscopic biological processes. $C B E$ Life Science Education, 8, 118-122.

Papadapoulos, C. \& Roman, A. S. (2010). Implementing an inverted classroom model in engineering statistics: Initial results. American Society for Engineering Statistics. Proceedings of the 40th ASEE/IEEE Frontiers in Education Conference, Washington, DC, October 2010
Rika. (2012). Perilaku Caring Perawat dalam Melakukan Asuhan Keperawatan pada Pasien di Ruang Rawat Inap RSUD Dr. Tengku Mansyur Tanjungbalai. Diunduh dari: www.repository.usu.ac.id

Strayer, J. (2012). How learning in an inverted classroom influences cooperation, innovation, and task Orientation. Learning Environments, 15(2), 171.

Valiga, T. "Nursing Education Trends: Future Implications and Predictions." Nursing Clinics of North America 47 (2012): 423-34 